Authors' Contribution:

A Study Design

B Data Collection

C Statistical Analysis

D Data Interpretation

E Manuscript Preparation

F Literature Search

G Funds Collection

\section{An assessment of the impact of special training of inspiratory muscles in a fitness classes programme on physical capacity of 20-25-year-old women}

\author{
Agnieszka Cybulska ABCDEF, Paweł Drobnik ABCDEF \\ Department of Methodology of Physical Education, \\ Gdansk University of Physical Education and Sport, Poland
}

abstract

Background

Material/Methods

Results

Conclusions

Key words

\section{article details}

Article statistics

Full-text PDF:

Copyright

Indexation:

Funding:

Conflict of interest: Corresponding author:

Open Access License:
In the process of modernising and improving physical fitness classes on offer, there is a growing trend to complement them with extra means characterized by different directions of interactions. Training of respiratory muscles (TRM) is one of them used in sports training but also increasingly more often in health training. The aim of the study was to assess changes in physical capacity under the influence of 6 weeks' training of a different type of inspiratory muscles incorporated into the programme of fitness classes for women aged 20-25 years.

The study involved 33 not training professionally young women aged 20-25 years. To assess the capacity of the respiratory sytem, dynamic spirometry was performed with a use of the K4b2 Spirometry apparatus by Cosmed company, and inspiratory muscle strength was measured with a use of a respiratory pressure meter by Micro Medical. Aerobic capacity was evaluated based on a direct method, using an incremental load test until exhaustion. Measurements were taken before and after a training session throughout six weeks with a frequency of three sessions per week.

As a result of a six-week special training in the POWERbreathe group there was a significant increase in spirometric indices compared to the initial measurement: FVC I (BTPS), FEV1 I (BTPS), PEF $\left(I \cdot \mathrm{sec}^{-1}\right), \operatorname{MVV}\left(\mathrm{I} \cdot \mathrm{min}^{-1}\right), \operatorname{MIP}\left(-\mathrm{mH}_{2} \mathrm{O}\right)$. However, apart from the above mentioned effects in the group of those training with bands also a significant increase in MEP $\left(\mathrm{cmH}_{2} \mathrm{O}\right)$ was noted compared to the control group.

The special inspiratory muscles training programme improved the functionality of the respiratory system, which is revealed in the increase in indicators characterizing aerobic capacity (with no significant influence on changing the body composition). The results obtained in our study indicate the possibility of practical application of respiratory training simulators in health and recreational physical activities enabling the growth of aerobic capacity of those exercising.

inspiratory muscles training, fitness, respiratory system, spirometry, capacity, young women

Word count: 3,969; Tables: 7; Figures: 0; References: 29

Received: September 2015; Accepted: November 2015; Published: December 2015

http://www.balticsportscience.com

(c) Gdansk University of Physical Education and Sport, Poland

AGRO, Celdes, CNKI Scholar (China National Knowledge Infrastructure), CNPIEC, De Gruyter - IBR (International Bibliography of Reviews of Scholarly Literature in the Humanities and Social Sciences), De Gruyter - IBZ (International Bibliography of Periodical Literature in the Humanities and Social Sciences), DOAJ, EBSCO - Central \& Eastern European Academic Source, EBSCO - SPORTDiscus, EBSCO Discovery Service, Google Scholar, Index Copernicus, J-Gate, Naviga (Softweco, Primo Central (ExLibris), ProQuest - Family Health, ProQuest - Health \& Medical Complete, ProQuest - Illustrata: Health Sciences, ProQuest - Nursing \& Allied Health Source, Summon (Serials Solutions/ProQuest, TDOne (TDNet), Ulrich's Periodicals Directory/ulrichsweb, WorldCat (OCLC)

This research received no specific grant from any funding agency in the public, commercial, or not-for-profit sectors.

Authors have declared that no competing interest exists.

Dr Paweł Drobnik, Gdansk University of Physical Education and Sport, Dep. of Methodology of Physical Education, ul. Kazimierza Gorskiego 1, 80-336 Gdansk, Poland; Phone number: +48605537674; e-mail: pdrobnik@awf.gda.pl

This is an open access article distributed under the terms of the Creative Commons Attribution-Non-commercial 4.0 International (http://creativecommons.org/licenses/by-nc/4.0/), which permits use, distribution, and reproduction in any medium, provided the original work is properly cited, the use is non-commercial and is otherwise in compliance with the license. 


\section{INTRODUCTION}

In the era of interest and increased focus on pro-healthy lifestyle, there is a growing need for scientific justification for optimization of physical activity to reduce health hazards. It is known that the purpose of physical recreation is to satisfy the needs for movement necessary for health as well as for maintenance of fitness and efficiency of the body. A dynamic development of different motor forms of a recreational and health nature, defined as fitness, fosters an increase in possibilities of adapting it to individual interests and capabilities of every person. The main goal of these activities is to increase and maintain at a satisfactory level the fitness and physical capacity supporting health.

Currently in fitness classes more and more attention is paid to the use of a large number of different in nature supporting means to increase the effectiveness of the implemented activities. Physical activity usually comprehensively affects an improvement in many aspects of human functional capacity, but it can also work selectively on some of them. To increase the effectiveness of such influences, special technical devices can be used, which additionally stimulate an increase in the different components of functional capabilities of an organism. It is assumed that some of the indicated influences can be adapted and used for pro-health purposes in the system of fitness training. Such actions may be based on a physiological assessment of a defined direction, scope and specificity of the obtained results. Broad impact concerns the training of respiratory muscles (TRM) as a supplement in increasing the capacity of the cardiopulmonary system along with a wide range of means, methods of application and the direction of impact. Numerous publications show the beneficial effect of the training of respiratory muscles among patients with diseases of the respiratory system. Such support is commonly used among patients suffering from bronchial asthma, emphysema as well as in children with scoliosis [1, 2]. The application of resistance exercises to respiratory muscles was also positively reflected in lung diseases [3, 4, 5, 6, 7]. The training of respiratory muscles, next to the medical aspects, has a widely described application also in professional sport with a view to increasing athletes' physical capacity.

Of much specialized equipment used for the training of respiratory muscles described in the world literature, in use are, among others, SpiroTiger ${ }^{\circledR}[8$, 9], Powerlung $[10,11]$ and POWERbreathe [12, 13]. A significant number of publications in the world literature also concern the application of the training of respiratory muscles among healthy non-training persons attesting to the functional improvement of the respiratory system $[6,14,15,16]$. Despite many studies available on the above issues, there are few that explain the impact of training of inspiratory muscles included in the program of fitness classes on an increase in the aerobic capacity of those exercising.

In this study, an assessment of changes under the influence of various types of training of inspiratory muscles included in a series of fitness classes on the capacity of young women is presented. 


\section{MATERIALS AND METHODS}

The study involved 33 women aged 20-25 years. In the course of the experiment, the women were not involved in other forms of fitness nor were they active athletes. In the first research group $(n=11)$, in addition to participation in a fitness class on stationary bikes, before and after the class women performed 3 sets of 20 inhalations and exhalations at $1 / 4$ of adjustment (in the initial phase), at increased resistance during inhalation and an interval of rest lasting 5 minutes. The inspiratory muscles resistance training was conducted with a use of POWERbreathe Sports Performance Classic. In the second, experimental group $(\mathrm{n}=11)$ a simulator was enabled in the form of an elastic band. The bands were used throughout the whole training unit on bikes with the strength of oppressive weight of $2.5 \mathrm{~kg}$. The study period covered six weeks with a frequency of three sessions a week, of 60 minutes each. The K4b2 Spirometry apparatus by Cosmed was used to assess the basic indicators of the respiratory system capacity. The strength of inspiratory muscles was measured on the basis of the maximum inspiratory and expiratory pressure in the oral cavity using the respiratory pressure meter by Micro Medical. Aerobic capacity was measured by means of the Quark b2 apparatus by Cosmed. The whole study was carried out based on a classical experiment method with initial and final measurements. The control group only realised the class programme on stationary bikes.

\section{FITNESS PROGRAMME AND TRAINING OF INSPIRATORY MUSCLES}

Aerobics on bikes is one of the more popular forms of fitness classes. During the study exercises were conducted on specially designed stationary bicycles with stable frames, equipped with controls to increase or decrease the resistance of the flywheel. All groups realised an endurance program, based on a continuous method with planned varied intensity, which was monitored by means of a Polar Team System set. A single class lasted 55-60 minutes.

\section{STATISTICAL ANALYSES}

Statistical analysis of the collected results was performed using STATISTICA 8. The module of the analysis of variance ANOVA - systems with repeated measurements was used. To examine the significance of the differences between results of the research groups in the experimental model, a comparison method by planned contrasts was used. The fact of meeting the assumptions of homogeneity of variance/covariance was verified by means of the Cochran, Hartley, Bartlett and Box tests. The study was designed and conducted according to an experimental plan with a control group with initial and final measurements of dependent variables. In addition, ANOVA with repeated measurements allowed detecting the effect of interactions. The research assumptions were verified at the level of significance $\alpha=0.05$ and the test likelihood $p \leq 0.05$. The study results and the discussion are presented in tables.

In Tables 1 and 2 values of the subjects' indicators of body composition before and after a training session are summarized. 
Table 1. Values of indicators of body composition in a group of women using POWERbreathe and in the control group before and after training of inspiratory muscles

\begin{tabular}{|c|c|c|c|c|}
\hline \multirow{2}{*}{ Parameters } & \multicolumn{2}{|c|}{ Before TRM } & \multicolumn{2}{|c|}{ After TRM } \\
\hline & POWERbreathe group & Control group & POWERbreathe group & Control group \\
\hline Mass (kg) & $61.81 \pm 9.35$ & $65.21 \pm 7.57$ & $61.56 \pm 9.25$ & $64.70 \pm 8.01$ \\
\hline $\mathrm{BMI}\left(\mathrm{kg} \cdot \mathrm{m}^{-2}\right)$ & $22.14 \pm 1.99$ & $23.36 \pm 2.68$ & $22.09 \pm 1.81$ & $23.56 \pm 3.10$ \\
\hline FAT $(\mathrm{kg})$ & $16.17 \pm 5.30$ & $18.89 \pm 6.02$ & $15.87 \pm 5.42$ & $18.74 \pm 6.13$ \\
\hline FAT (\%) & $24.27 \pm 5.54$ & $26.05 \pm 5.35$ & $24.83 \pm 5.12$ & $28.42 \pm 6.11$ \\
\hline FFM $(\mathrm{kg})$ & $46.01 \pm 3.85$ & $45.92 \pm 2.19$ & $46.20 \pm 3.25$ & $46.05 \pm 2.44$ \\
\hline
\end{tabular}

The results are presented as means $(X)$ and standard deviations $(\delta)$

Table 2. Values of indicators of body composition in the group with elastic bands and in the control group before and after training of inspiratory muscles

\begin{tabular}{|c|c|c|c|c|}
\hline \multirow[b]{2}{*}{ Parameters } & \multicolumn{2}{|c|}{ Before TRM } & \multicolumn{2}{|c|}{ After TRM } \\
\hline & $\begin{array}{l}\text { Elastic bands } \\
\text { group }\end{array}$ & Control group & $\begin{array}{l}\text { Elastic bands } \\
\text { group }\end{array}$ & Control group \\
\hline Mass (kg) & $64.62 \pm 9.48$ & $65.21 \pm 7.57$ & $64.90 \pm 9.42$ & $64.7 \pm 8.01$ \\
\hline BMI $\left(\mathrm{kg} \cdot \mathrm{m}^{-2}\right)$ & $22.51 \pm 1.98$ & $23.36 \pm 2.68$ & $22.68 \pm 2.03$ & $23.56 \pm 3.10$ \\
\hline FAT (kg) & $18.55 \pm 6.89$ & $18.89 \pm 6.02$ & $18.52 \pm 6.67$ & $18.74 \pm 6.13$ \\
\hline FAT (\%) & $26.31 \pm 6.12$ & $26.05 \pm 5.35$ & $27.52 \pm 6.81$ & $28.42 \pm 6.11$ \\
\hline FFM (kg) & $46.51 \pm 3.13$ & $45.92 \pm 2.19$ & $46.65 \pm 3.16$ & $46.05 \pm 2.44$ \\
\hline
\end{tabular}

The results are presented as means $(\bar{X})$ and standard deviations $(\delta)$

Table 3 shows the statistical characteristics of the values of indicators describing the respiratory system capacity among the group of women using POWERbreathe devices and women of the control group before and after completing of training of inspiratory muscles.

Table 3. Changes in the values of indicators characterizing the respiratory system capacity in the group of women using POWERbreathe devices and in the control group before under the influence of 6-week training of inspiratory muscles

\begin{tabular}{|c|c|c|c|c|}
\hline \multirow{2}{*}{ Parameters } & \multicolumn{2}{|c|}{ Before TRM } & \multicolumn{2}{|c|}{ After TRM } \\
\hline & POWERbreathe group & Control group & POWERbreathe group & Control group \\
\hline FVC I (BTPS) & $3.96 \pm 0.38$ & $3.75 \pm 0.42$ & $4.35 \pm 0.69 *$ & $3.94 \pm 0.38$ \\
\hline FEV1 I (BTPS) & $3.19 \pm 0.40$ & $3.15 \pm 0.50$ & $3.60 \pm 0.30 * *$ & $3.28 \pm 0.30$ \\
\hline $\operatorname{PEF}\left(\mid \cdot S^{-1}\right)$ & $6.66 \pm 1.16$ & $6.21 \pm 1.29$ & $7.83 \pm 1.37^{*}$ & $7.23 \pm 0.71 *$ \\
\hline PIF $\left(\mid \cdot S^{-1}\right)$ & $1.32 \pm 0.28$ & $1.55 \pm 0.59$ & $1.64 \pm 0.49$ & $1.66 \pm 0.58$ \\
\hline $\operatorname{MVV}\left(I \cdot \mathrm{min}^{-1}\right)$ & $131.47 \pm 8.30$ & $128.16 \pm 9.40$ & $142.10 \pm 11.0 *$ & $134.90 \pm 12.60$ \\
\hline $\operatorname{MIP}\left(-\mathrm{cmH}_{2} \mathrm{O}\right)$ & $95.73 \pm 16.01$ & $90.64 \pm 19.75$ & $113.55 \pm 17.06 *$ & $98.09 \pm 20.34$ \\
\hline $\operatorname{MEP}\left(\mathrm{cmH}_{2} \mathrm{O}\right)$ & $120.49 \pm 17.11$ & $121.15 \pm 13.65$ & $130.36 \pm 14.04$ & $128.0 \pm 13.34$ \\
\hline
\end{tabular}

The results are presented as means $(\bar{X})$ and standard deviations $(\delta)^{*}$ a statistically significant change in the results of the group in comparison to the initial results $(p \leq 0.05)$

** a statistically significant change in comparison to the control group $(p \leq 0.05)$ - an experimental effect

Table 4 compiles values of selected indicators characterizing the efficiency of the respiratory system among women using elastic bands in comparison to women from the control group. 
Table 4. Values of indicators of the respiratory system capacity in the group of women using the inspiratory muscles training with elastic bands and in the control group before and after six weeks of training

\begin{tabular}{lcccc}
\hline \multirow{2}{*}{ Parameters } & \multicolumn{2}{c}{ Before TRM } & \multicolumn{2}{c}{ After TRM } \\
\cline { 2 - 5 } & Elastic bands group & Control group & Elastic bands group & Control group \\
\hline FVC I(BTPS) & $3.93 \pm 0.52$ & $3.75 \pm 0.42$ & $4.23 \pm 0.71$ & $3.94 \pm 0.38$ \\
\hline FEV1 I(BTPS) & $3.18 \pm 0.4$ & $3.15 \pm 0.50$ & $3.35 \pm 0.41$ & $3.28 \pm 0.30$ \\
\hline PEF $\left(\mid \cdot\right.$ sek $\left.^{-1}\right)$ & $6.28 \pm 1.43$ & $6.21 \pm 1.29$ & $7.31 \pm 0.76 *$ & $7.23 \pm 0.71 *$ \\
\hline PIF $\left(\mid \cdot\right.$ sek $\left.^{-1}\right)$ & $1.33 \pm 0.52$ & $1.55 \pm 0.59$ & $1.79 \pm 0.8$ & $1.66 \pm 0.58$ \\
\hline MVV $\left(\mid \cdot \mathrm{min}^{-1}\right)$ & $130.38 \pm 11.22$ & $128.2 \pm 9.40$ & $143.6 \pm 11.1 *$ & $134.9 \pm 12.60$ \\
\hline MIP $\left(-\mathrm{cmH}_{2} \mathrm{O}\right)$ & $96.45 \pm 14.7$ & $90.64 \pm 19.75$ & $111.09 \pm 15.71 *$ & $98.09 \pm 20.34$ \\
\hline MEP $\left(\mathrm{cmH}_{2} \mathrm{O}\right)$ & $121.55 \pm 18.38$ & $121.15 \pm 13.7$ & $132.0 \pm 21.41 *$ & $128.0 \pm 13.3$ \\
\hline
\end{tabular}

The results are presented as means $(\bar{X})$ and standard deviations $(\delta)$

* a statistically significant change in the results of the group in comparison to the initial results $(p \leq 0.05)$

Table 5 shows the statistical characteristics of differences in aerobic capacity indicators between the group of women using the POWERbreathe devices and the control group before and after training of inspiratory muscles.

Table 5. Values of aerobic capacity indicators in the group of women using POWERbreathe devices and women in the control group

\begin{tabular}{|c|c|c|c|c|}
\hline \multirow{3}{*}{ Parameters } & \multicolumn{2}{|c|}{ Before TRM } & \multicolumn{2}{|c|}{ After TRM } \\
\hline & $\begin{array}{l}\text { POWERbreathe } \\
\text { group }\end{array}$ & Control group & POWER breathe group & Control group \\
\hline & $\bar{X} \pm \delta$ & $\bar{X} \pm \delta$ & $\bar{X} \pm \delta$ & $\bar{X} \pm \delta$ \\
\hline $\mathrm{VT}_{\max }(\mathrm{I})$ & $1.83 \pm 0.24$ & $1.86 \pm 0.27$ & $2.28 \pm 0.38 *$ & $1.96 \pm 0.36$ \\
\hline$V E_{\text {max }}\left(I \cdot \min ^{-1}\right)$ & $82.71 \pm 13.1$ & $79.43 \pm 8.56$ & $95.22 \pm 15.21 * *$ & $82.11 \pm 13.27$ \\
\hline $\mathrm{VE} \cdot \mathrm{VO}_{2}^{-1}$ with max power & $37.24 \pm 5.84$ & $33.81 \pm 5.43$ & $36.81 \pm 5.9$ & $32.99 \pm 5.22$ \\
\hline $\mathrm{VO}_{2} \cdot \mathrm{HR}^{-1}$ with max power & $11.81 \pm 1.31$ & $11.94 \pm 1.2$ & $13.15 \pm 1.22 *$ & $12.15 \pm 1.13$ \\
\hline$H R_{\max }\left(b t \cdot \min ^{-1}\right)$ & $184.91 \pm 3.96$ & $185.00 \pm 3.46$ & $185.27 \pm 3.98$ & $187.45 \pm 2.21$ \\
\hline $\mathrm{VO}_{2 \max }\left(\mathrm{ml} \cdot \mathrm{min}^{-1}\right)$ & $2177.9 \pm 259.8$ & $2192.7 \pm 273.8$ & $2430.1 \pm 209.1 *$ & $2276.8 \pm 230.7$ \\
\hline $\mathrm{VO}_{2 \max }\left(\mathrm{ml} \cdot \mathrm{kg}^{-1} \cdot \mathrm{min}^{-1}\right)$ & $35.74 \pm 5.23$ & $33.86 \pm 4.57$ & $39.99 \pm 5.2 * *$ & $35.51 \pm 4.41$ \\
\hline Power $_{\max }(\mathrm{W})$ & $206.82 \pm 22.61$ & $204.55 \pm 24.54$ & $235.91 \pm 23.65 * *$ & $209.09 \pm 20.23$ \\
\hline Power $_{\max }\left(\mathrm{W} \cdot \mathrm{kg}^{-1}\right)$ & $3.40 \pm 0.57$ & $3.16 \pm 0.42$ & $3.89 \pm 0.58 * *$ & $3.34 \pm 0.63$ \\
\hline AT VE $\left(\mid \cdot \min ^{-1}\right)$ & $44.86 \pm 6.55$ & $43.68 \pm 8.56$ & $52.32 \pm 7.71^{* *}$ & $44.79 \pm 5.12$ \\
\hline AT VO ${ }_{2}\left(\mathrm{ml} \cdot \mathrm{min}^{-1} \cdot \mathrm{kg}^{-1}\right)$ & $26.40 \pm 4.48$ & $24.53 \pm 3.25$ & $30.07 \pm 3.80 * *$ & $25.71 \pm 2.71$ \\
\hline
\end{tabular}

The results are presented as means $(\bar{X})$ and standard deviations $(\delta)$

* a statistically significant change in the results of the group in comparison to the initial results $(p \leq 0.05)$

** a statistically significant change in comparison to the control group ( $p \leq 0.05)$ - an experimental effect

An analysis of values of indicators characterizing aerobic capacity and their changes under the influence of training of inspiratory muscles with a use of elastic bands is presented in Table 6 . 
Table 6. Values of aerobic capacity indicators in the group of women using elastic bands and women in the control group

\begin{tabular}{|c|c|c|c|c|}
\hline \multirow{2}{*}{ Parameters } & \multicolumn{2}{|c|}{ Before TRM } & \multicolumn{2}{|c|}{ After TRM } \\
\hline & Elastic bands group & Control group & Elastic bands group & Control group \\
\hline $\mathrm{BF}_{\max }\left(\right.$ since $\left.\cdot \min ^{-1}\right)$ & $42.01 \pm 8.18$ & $42.13 \pm 6.90$ & $42.01 \pm 8.04$ & $42.35 \pm 6.37$ \\
\hline $\mathrm{VT}_{\max }(\mathrm{I})$ & $1.99 \pm 0.43$ & $1.86 \pm 0.27$ & $2.2 \pm 0.34$ & $1.96 \pm 0.36$ \\
\hline$V E_{\max }\left(I \cdot \min ^{-1}\right)$ & $84.52 \pm 17.76$ & $79.43 \pm 8.56$ & $94.25 \pm 14.88^{*}$ & $82.11 \pm 13.27$ \\
\hline $\mathrm{VE} \mathrm{VO}{ }_{2}^{-1} \max$ & $36.71 \pm 1.92$ & $33.81 \pm 5.49$ & $35.20 \pm 4.70$ & $32.99 \pm 5.22$ \\
\hline $\mathrm{VO}_{2} \mathrm{HR}^{-1}{ }_{\text {max }}$ & $12.58 \pm 2.42$ & $11.94 \pm 1.20$ & $13.82 \pm 2.20^{* *}$ & $12.15 \pm 1.13$ \\
\hline $\mathrm{HR}_{\max }\left(\mathrm{bt} \cdot \mathrm{min}^{-1}\right)$ & $187.18 \pm 4.45$ & $185.0 \pm 3.46$ & $188.09 \pm 5.38$ & $187.45 \pm 2.21$ \\
\hline $\mathrm{VO}_{2 \max }\left(\mathrm{ml} \cdot \mathrm{min}^{-1}\right)$ & $2283.6 \pm 382.5$ & $2192.7 \pm 273.8$ & $2531.3 \pm 416.3^{* *}$ & $2276.8 \pm 230.7$ \\
\hline $\mathrm{VO}_{2 \max }\left(\mathrm{ml} \cdot \mathrm{kg}^{-1} \cdot \mathrm{min}^{-1}\right)$ & $35.52 \pm 5.20$ & $33.86 \pm 4.57$ & $39.36 \pm 5.76^{* *}$ & $35.51 \pm 4.41$ \\
\hline Power $_{\text {max }}(\mathrm{W})$ & $204.55 \pm 31.26$ & $204.55 \pm 24.54$ & $234.09 \pm 28.0 * *$ & $209.09 \pm 20.23$ \\
\hline Power $_{\max }\left(\mathrm{W} \cdot \mathrm{kg}^{-1}\right)$ & $3.19 \pm 0.45$ & $3.16 \pm 0.42$ & $3.65 \pm 0.44 *$ & $3.34 \pm 0.63$ \\
\hline AT VO $\mathrm{O}_{2}\left(\mathrm{ml} \cdot \mathrm{min}^{-1} \cdot \mathrm{kg}^{-1}\right)$ & $26.25 \pm 4.43$ & $24.53 \pm 3.25$ & $29.56 \pm 4.13^{* *}$ & $25.71 \pm 2.71$ \\
\hline AT (W) & $131.82 \pm 22.61$ & $138.64 \pm 20.5$ & $159.1 \pm 23.1^{* *}$ & $147.73 \pm 17.5$ \\
\hline
\end{tabular}

The results are presented as means $(\bar{X})$ and standard deviations $(\delta)$

* a statistically significant change in the results of the group in comparison to the initial results $(p \leq 0.05)$

** a statistically significant change in comparison to the control group $(p \leq 0.05)$ - an experimental effect

Table 7 shows the mean values of the heart rate recorded during fitness classes on stationary bikes.

Table 7. Value of the heart rate during classes on stationary bikes in the tested groups of women

\begin{tabular}{|c|c|c|c|}
\hline \multirow{3}{*}{ Parameters } & POWERbreathe group & Elastic band group & Control group \\
\hline & & & \\
\hline & $\bar{X} \pm \delta$ & $\bar{X} \pm \delta$ & $\bar{X} \pm \delta$ \\
\hline $\mathrm{HR}\left(\mathrm{bt} \cdot \mathrm{min}^{-1}\right)$ & $146.69 \pm 9.15$ & $148.41 \pm 11.86$ & $146.80 \pm 11.18$ \\
\hline$H R_{\max }\left(b t \cdot \min ^{-1}\right)$ & $176.88 \pm 6.54$ & $178.42 \pm 7.47$ & $177.65 \pm 7.67$ \\
\hline
\end{tabular}

The results are presented as means $(\bar{X})$ and standard deviations $(\delta)$

\section{RESULTS}

The final results of the six weeks' study involving women aged 20-25 years, divided into separate research groups (POWERbreathe, elastic bands, control) with a different type of inspiratory muscle training, showed specific changes or a complete lack thereof (indicators of body composition - Tables 1 and 2) within the measured values of the indicators. In the groups of women training with a use of both POWERbreathe and elastic bands, a significant growth of respiratory indicators: FEV, FEV1, MVV, MIP in comparison to the first measurement was noted, without significant changes in the control group. This indicates an increase in inspiratory muscles strength and an improvement in the respiratory system capacity in the experimental groups (Tables 3 and 4). Special training of inspiratory muscles, included in the programme of six-week fitness classes, caused an increase in the participants' aerobic capacity. The 
basic indicator proving the discussed change - the maximum oxygen uptake - in groups with added means for inspiratory training significantly increased in comparison to the first test and in comparison to the control group. In the group using the POWERbreathe device the increase ranged from $35.74 \pm 5.23$ to $39.99 \pm 5.20$ (Tables 3 and 5) $\mathrm{VO}_{2 \max }\left(\mathrm{ml} \cdot \mathrm{kg}^{-1} \cdot \mathrm{min}^{-1}\right.$ ), in the group using elastic bands from $35.52 \pm 5.20$ to $39.36 \pm 5.76 \mathrm{VO}_{2 \max }\left(\mathrm{ml} \cdot \mathrm{kg}^{-1} \cdot \mathrm{min}^{-1}\right)$, while in the control group the final result was only $35.51 \pm 4.41 \mathrm{VO}_{2 \max }\left(\mathrm{ml} \cdot \mathrm{kg}^{-1} \cdot \mathrm{min}^{-1}\right)$ (Table 6). Also in measurements determining the volume of the anaerobic threshold, substantial changes in oxygen uptake were revealed. The following results were obtained in the initial and final stages of the research process: from $26.4 \pm 4.48$ to $30.07 \pm 3.80 \mathrm{VO}_{2 \max }\left(\mathrm{ml} \cdot \mathrm{kg}^{-1} \cdot \mathrm{min}^{-1}\right)$ in the POWERbreathe users, from $26.25 \pm 4.43$ to $29.56 \pm 4.13 \mathrm{VO}_{2 \max }\left(\mathrm{ml} \cdot \mathrm{kg}^{-1} \cdot \mathrm{min}^{-1}\right)$ in the group exercising with elastic bands (Table 6 ), and from $24.53 \pm 3.25$ to $25.71 \pm 2.71$ (ml-kg-1·min-1) in the control group (Tables 5 and 6), which, in contrast to the experimental groups showed no statistically significant difference. Higher values of the $\mathrm{AT} \mathrm{VO}_{2}$ indicator $\left(\mathrm{ml} \cdot \mathrm{min}^{-1} \cdot \mathrm{kg}^{-1}\right)$ in the group of women exercising with bands are also confirmed by a significant effect of interaction. The increase in this index in the experimental group was significantly higher than that observed among participants from the control group, and it also coincided with the experimental result. Values of the heart rate shown in Table 7 during the whole series of fitness classes indicate that the work was performed mainly at the level of moderate and high intensity at an average of $146.69 \pm 9.15$ to $177.65 \pm 7.67 \mathrm{HR}\left(\mathrm{bt} \cdot \mathrm{min}^{-1}\right)$ during a class unit ( $\left.\mathrm{t}=60 \mathrm{~min}\right)$. The level of load performed during classes on stationary bikes did not significantly differ among the various research groups.

In conclusion, it should be noted that the training of inspiratory muscles, different in the way of implementation, included in a serious of recreational fitness classes contributed to an increase in the desired functional capacity of the respiratory system and an increase in aerobic capacity.

\section{DISCUSSION}

The current trend of healthy lifestyles together with a desire to improve fitness and efficiency of an organism demand additional measures to stimulate the development of effort capabilities in healthy people. Training of respiratory muscles (TRM) included in a series of health and sports training may constitute such support.

In studies of highly qualified athletes it was proved that, as a result of training of inspiratory muscle, the volume of ventilatory threshold (VT) and maximal inspiratory pressure ( $\mathrm{PI}_{\max }$ ) increased. According to the authors, this effect demonstrates a more economical operation of the respiratory system. Although no significant changes in the maximal oxygen consumption $\left(\mathrm{VO}_{2 \max }\right)$ were noted, an increase in work efficiency was most likely caused by reduced absorption of oxygen by respiratory muscles in favour of the working leg muscles [17]. Morgan et al. [18] proved positive effects of training of respiratory muscles in a group of trained cyclists. These scientists observed that after three weeks of directed training of respiratory muscles the level of maintaining the respiratory minute volume at a level of $100 \%$ MVV (measured within 15 seconds) significantly increased from 48 to 804 seconds [18]. 
Similar results are confirmed by Spengler and Boutellier's [8] research showing that training of inspiratory muscles had a beneficial effect on the extension of maintaining the respiratory minute volume at a load of $71 \%$ of the maximal voluntary ventilation (MVV) from 5 to 29 minutes. Subjects performed work at this level without clear signs of fatigue of the respiratory system. The change was registered in 19 out of 20 examined athletes. A reduced concentration of lactic acid at the final stage of the stress test was observed. According to the authors, the reduction of lactate in blood was most likely caused by its improved disposal by trained respiratory muscles [8].

Training of respiratory muscles, as an additional supporting measure, was conducted among athletes of many sports disciplines, among others, top cyclists [12], athletes of endurance events [19, 20], or among highly trained rowers [21]. Amonette and Dupler assessed the effects of training of respiratory muscles among professional triathletes. After applying the respiratory training with a use of an inspiratory resistance device Powerlung, changes in the cardio-respiratory system were observed in the experimental group, and this was an increase in the maximal minute ventilation of the lungs $\left(\mathrm{VE}_{\max }\right)$ by $3.29 \%$ and the maximal ventilatory threshold $\left(\mathrm{VT}_{\max }\right)$ by $26.73 \%$. In spirometric measurements no significant changes in other measured indicators were noted in the experimental group, except for an increase in the peak inspiratory flow (PIF) by $23.35 \%$. Likewise, no significant increase in the maximum oxygen uptake was noted. According to the authors, such changes could be observed in training of more than 8-12 weeks [22]. Inbar et al. confirmed a positive influence of training of respiratory muscles based on 10 weeks' study involving athletes of endurance events. The authors concluded that resistance training with a use of a Powerlung device applied to top athletes resulted in a significant increase in the maximal strength and endurance of inspiratory muscles, thus enhancing exercise potential of the athletes' respiratory system. Despite a significant increase in the value of spirometric indices, no significant increase in the maximal oxygen uptake $\left(\mathrm{VO}_{2 \max }\right)$ during a stress test was revealed [23].

Publications on the application of training of respiratory muscles in healthy not training persons also have a significant place in the world literature [6, $14,15]$. In all the studies this type of training was conducted in the form of systematic breathing exercises of a strength or endurance character with a use of appropriately chosen training means and with a diversified duration [24]. Nurmekivi et al. showed that special exercises aimed at developing respiratory muscles increase their ability to work more than general physical exercise. In people who exercise the frequency of breaths decreases with their simultaneous deepening, and fatigue manifests itself later and with smaller effects than in persons not applying special training. It was also observed that people who had not done any special breathing exercises, interrupted physical effort due to fatigue of the lower limbs muscles. Because there were no signs of fatigue in the way of breathing in these individuals, it seems reasonable to hypothesise that breathing muscles made up for their own oxygen consumption at the expense of working muscles of the legs. Hence it can be concluded that reduced lung ventilation, which is a consequence of training of respiratory muscles, indicates a more economical work of the respiratory system [25, 26]. In order to compare the effectiveness of training of respiratory muscles of a different direction and impact, O'Kroy and Coast conducted a study invo- 
lving healthy untrained people. On completion of the study period there was an increase in maximal inspiratory pressure (MIP) and maximal inspiratory flow at the desired point of forced inspiration (MFIs) [27]. The latest scientific reports by Mills et al. confirm a positive impact of inspiratory muscles resistance training practised by the elderly. Respiratory muscles, performing a continuous work, are subject to involution processes during ontogeny. This leads to a natural weakening of their structure, strength and endurance. In addition, inflammations and diseases can contribute to seniors' morbidity and mortality. Research indicates that in the elderly healthy subjects respiratory training has several positive changes, among others: increase in maximal inspiratory pressure and thus the inspiratory muscle strength and peak inspiratory flow [28]. Of interest are the results of a study conducted by Kim CY et al. [29], which proved that inspiratory muscles training can improve the lung function among people living with hemiplegia after stroke [29].

At the present stage of constant interest in the impact of training of respiratory muscles on exercise capacity, individual issues have already been confirmed by scientific research. It has been proved that such training, among others, increases strength and reduces the fatigue of respiratory muscles, improves the functional capacity of the respiratory system, reduces the sense of breathlessness during effort and reduces oxygen consumption by respiratory muscles in favour of other skeletal muscles. Our studies on healthy, untrained women confirm the positive impact of TRM integrated into a series of fitness classes to increase the capacity of exercising women. The study was conducted using a device enabling a greater inspiratory resistance - POWERbreathe, and for the first time, the effect of the use of elastic bands placed on the lower part of the chest on increasing the respiratory system capacity in young women was examined. In different proportions the research reported significant increases in spirometric FVC, FEV1, MVV, MIP, MEP, and PEF. In addition, a significant increase in the following functional indicators was confirmed: $\mathrm{VO}_{2}\left(\mathrm{ml} \cdot \mathrm{min}^{-1} \cdot \mathrm{kg}^{-1}\right), \mathrm{AT} \mathrm{VO}_{2}\left(\mathrm{ml} \cdot \mathrm{min}^{-1} \cdot \mathrm{kg}^{-1}\right), \mathrm{VO}_{2} \mathrm{HR}^{-1}{ }_{\max }, \mathrm{VE}_{\max }\left(1 \cdot \mathrm{min}^{-1}\right)$ among 20-25-year-old women in both groups applying additional respiratory training simulators.

Collected and presented above results broadly confirm the expected effects of the experiment. In addition, the obtained results together with an in-depth analysis may serve as the basis for the use of inspiratory muscles training in modern forms of health training.

\section{CONCLUSIONS}

Special inspiratory muscles training with a use of the PowerBreathe device and with elastic bands included in the program of fitness classes improved the functionality of the respiratory system within indicators: (FVC), (FEV1), (PEF), (PIF), (MVV) as well as (MIP) and (MEP). Inspiratory muscles training using POWERbreathe and elastic bands significantly affects the increase in indicators characterizing aerobic capacity: $\mathrm{VO}_{2} \max \left(\mathrm{ml} \cdot \mathrm{kg}^{1} \cdot \mathrm{min}^{-1}\right)$, $\mathrm{VE}_{\max }\left(1 \cdot \mathrm{min}^{-1}\right)$, ventilatory equivalent of oxygen consumption $\left(\mathrm{VE} \cdot \mathrm{O}_{2}^{-1}\right.$ max $)$, the oxygen-pulse coefficient $\left(\mathrm{VO}_{2} \cdot \mathrm{HR}^{-1}{ }_{\max }\right)$, and the highest recorded power (W). The above inspiratory muscles training with additional complementary measures had no significant influence on changing the body composition. 
The results obtained in our study indicate the possibility of practical application of respiratory training simulators in health and recreational physical activities enabling the growth of aerobic capacity of those exercising.

\section{REFERENCES}

[1] Walczak J, Koziorowski A. Wyniki treningu mięśni oddechowych na przewlekłą obturacyjna chorobę płuc o średnio ciężkim przebiegu [Results of the training of respiratory muscles on chronic obstructive pulmonary disease of average severity]. Pneumonologia i Alergologia Polska. 1997;65(78):487-493. Polish.

[2] Dyner-Jama I, Dobosiewicz K, Niepsuj K, Niepsuj G, Jędrzejewska A, Czernicki K. Wpływ leczenia metodą asymetrycznych ćwiczeń oddechowych na czynność układu oddechowego, ocenianą za pomocą badania spirometrycznego u dzieci z idiopatycznym bocznym skrzywieniem kręgosłupa [Effect of treatment with the method of asymmetrical breathing exercises on the pulmonary function as measured by spirometry in children with idiopathic scoliosis]. Wiadomości Lekarskie. 2000;53(1112):603-610. Polish.

[3] Beaumont M, Milon P, Ber-Moy CL, et al. Inspiratory muscle training during pulmonary rehabilitation in chronic obstructive pulmonary disease: A randomized trial. Chronic Respiratory Disease. 2015;12(4):305-312.

[4] Villanfranca CG, Leiva A, Lisboa C. Effects of inspiratory muscle training with an intermediate on inspiratory power output in COPD. Eur Respir J. 1998;10(8):542-547.

[5] Weiner P, Magadle R, Beckerman M, Weiner M, Berar-Yanay N. Comparison of Specific Expiratory, Inspiratory, and Combined Muscle Training Programs in COPD. Chest. 2003;4, 1537-1364.

[6] McConeell AK, Weiner P, Romer LM. Inspiratory muscle training as a tool for the management of patients with COPD. Eur Respir J. 2004;24:510-514.

[7] Charususin N, Gosselink R, Decramer M, et al. Inspiratory muscle training protocol for patients with chronic obstructive pulmonary disease (IMTCO study): a multicentre randomised controlled trial. BMJ Open. 2013;3(8):e003101.

[8] Splengler C, Boutellier U. Breathless legs? Consider trainining your respiration. News Physiol Sci. 2000;15:102-105.

[9] Stuessi Ch, Spengler Ch, Knópfli-Lenzin C, Markov G, Boutellier U. Respiratory muscle endurance training in humans increases cycling endurance without affecting blood gas concentrations. Eur J Appl Physiol. 2001;84:582-586.

[10] Miszczenko W, Tomiak T. Kierunki zmiany możliwości funkcjonalnych i zdolności wysiłkowej zawodników wywołane różnymi rodzajami treningu mięśni oddechowych [Directions of changes in athletes' functional capacity and exercise capacity caused by various types of training of respiratory muscles]. In: Kuder A, Perkowski K, Śledziewski D, eds. Kierunki doskonalenia treningu i walki sportowej: diagnostyka [Trends in improving training and sportsmanship: diagnostics]. Warszawa: AWF; 2004, 106-109. Polish.

[11] Guenette JA, Martens AM, Lee AL, et al. Variable effects of respiratory muscle training on cycle exercise performance in men and women. Applied Physiology Nutrition Metabolism 2006;2:159-166.

[12] Romer LM, McConnell AK, Jones D.A., Effects of inspiratory muscle training on time trial performance in trained cyclists. J Sport Med. 2002;20:547-562.

[13] Romer LM, McConnell AK. Specificity and reversibility of inspiratory muscle training. Med Sci Sports Exerc 2003;35:237-244.

[14] Boutellier U. Respiratory muscle fitness and exercise endurance in healthy humans. Med Sci Sports Exerc. 1998;30:1169-1172.

[15] Edwards AM, Cooke CB. Oxygen uptake kinetics and maximal aerobic power are unaffected by inspiratory muscle training in healthy subjects where time to exhaustion is extended. Eur J Appl Physiol. 2004;93:139-144

[16] Enright SJ, Unnithan VB, Heward C, Withnall L, Davies DH. Effect of high-intensity inspiratory muscle training on lung volumes, diaphragm thickness, and exercise capacity in subjects who are healthy. Physical Therapy. 2006;86(3):345-54

[17] Volianitis S, McConnell A, Koutedakis Y, McNaughton L, Back K, Jones DA. Inspiratory muscle training rowing performance. Med Sci Sports Exerc. 2003;33(5):803-809.

[18] Morgan DW, Kohr WM, Bates BJ, Skinner JS. Effects of respiratory muscle endurance training on ventilatory and endurance performance of moderately trained cyclists. Int J Sport Med. 1987;08(2):88-93.

[19] Boutellier U, Piwko P. The Respiratory system as an exercise limiting factor in normal sedentary subjects. Eur J Appl Physiol. 1992;64:145-15.

[20] HajGhanbari B, Yamabayashi C, Buna TR, et al. Effects of respiratory muscle training on performance in athletes: a systematic review with meta-analyses. J Strength Cond Res. 2013;27:1643-1663.

[21] Griffiths LA, McConnell AK. The influence of inspiratory and expiratory muscle training upon rowing performance. Eur J Appl Physiol. 2007;99(5):457-66.

[22] Amonette WE, Dupler TL. The effects of respiratory muscle training on VO2 max, the ventilatory threshold and pulmonary function. J Exerc Physiol. 2002;5(2):29-35. 
[23] Inbar O, Weiner P, Azgad Y, Rotstein A, Weinstein Y. Specific inspiratory muscle training in well-trained endurance athletes. Med Sci Sports Exerc. 2000;32(7):1233-1237.

[24] Markov G, Spengler ChM, Lenzin CK, Boutellier U. Respiratory muscle training increases cycling endurance without affecting cardiovascular responses to exercise. Eur J Appl Physiol. 2001;85:233-239.

[25] Nurmekivi A, Kingisepp P.H. Capacity of the respiratory system and the potential to influence it. Modern Athlete and Coach. 2000;38:8-12.

[26] Romer LM, Lovering AT, Haverkamp HC, Pegelow DF, Dempsey A. Effect of inspiratory muscle work on peripheral fatigue of locomotor muscle in healthy humans. J Physiol. 2006;571(2):425-439.

[27] O'Kroy JA, Coast DE. Effects of flow and resistive training on respiratory muscle endurance and strength. Respiration. 1993;60(5):279-283.

[28] Mills DE, Johnson MA, Barnett YA, Smith WH, Sharpe GR. The effects of inspiratory muscle training in older adults. Med Sci Sports Exerc. 2015;47(4):691-697.

[29] Kim CY, Lee JS, Kim HD, Kim IS. Effects of the combination of respiratory muscle training and abdominal drawing-in manoeuvre on respiratory muscle activity in patients with post-stroke hemiplegia: a pilot randomized controlled trial. Top Stroke Rehabilitation. 201;22(4):262-270. 